\title{
PELATIHAN KARYA TULIS DAN MAJALAH DINDING BAGI SISWA MADRASAH TSANAWIYAH AL MADANIYAH JEMPONG AMPENAN MATARAM
}

\author{
Lukman Hakim \\ Universitas Islam Negeri Mataram \\ lukmanhakimvictor@gmail.com
}

\begin{abstract}
Abstrak: Kegiatan pengabdian ini dilakukan untuk memberikan Pelatihan Karya Tulis dan Majalah Dinding Bagi Siswa Madrasah Tsanawiyah Al Madaniyah Jempong Ampenan Mataram. Terdapat beberapa tujuan yang ingin dicapai dari kegiatan ini, yaitu; untuk mendeskripsikan potensi menulis dan berkreasi dalam mengekpresikan diri atau kelompok dalam bahasa tulis dan simbol bagi siswa, mendeskripsikan cara membuat dan mengelola majalah dinding sebagai media karya dan komunikasi pada komunitas, dan mendeskripsikan cara pemanfaatan media untuk berekpresi secara positif dan produktif. Pelatihan ini menggunakan metode ceramah dan simulasi serta praktek membuat tulisan karya tulis dan membuat majalah dinding di madrasah. Kesimpulan yang diperoleh dari kegiatan pengabdian ini adalah adalah (1) secara kognitif ada peningkatan pengetahuan siswa dalam penulisan karya tulis dan majalah dinding, (2) siswa memiliki keterampilan dasar dalam menulis karya tulis dan membuat majalah dinding, (3) siswa dapat menuangkan ide kreatif dalam mengembangkan hasil kreasi dan variasi model keterampilan dalam karya tulis dan majalah dinding, dan (4) siswa dapat menerbitkan hasil karya tulis mereka dalam majalah dinding.
\end{abstract}

Kata kunci: pelatihan, karya tulis, majalah dinding, madrasah

\begin{abstract}
This community service is carried out to provide Writing and Wall Magazines Training for Madrasah Tsanawiyah Al Madaniyah Jempong Ampenan Mataram Students. There are several objectives to be achieved from this activity, namely; to describe the potential of writing and being creative in expressing themselves or groups in written language and symbols for students, describe how to make and manage wall magazines as a medium of work and communication in the community, and describe how to use media to express positively and productively. This training uses lecture and simulation methods as well as the practice of writing papers and making wall magazines in the madrasa. The conclusions obtained from this activity are (1) cognitively increasing students' knowledge in writing and wall magazines, (2) students have basic skills in writing papers and making wall magazines, (3) students can put creative ideas in developing the creation and variation of skill models in wall papers and magazines, and (4) students can publish their written work in wall magazines.
\end{abstract}

Keywords: training, papers, wall magazine, madrasa

\section{Pendahuluan}

Salah satu tugas utama dosen adalah pengabdian kepada masyarakat, hal ini untuk memenuhi Tri Darma Perguruan Tinggi, kewajiban yang niscaya harus dipenuhi di samping fungsi dan tugas pengajaran serta penelitian. Implementasi pengabdian kepada masyarakat yang dapat dilakukan dalam upaya peningkatan kualitas Sumber Daya Manusia Indonesia. Oleh karena itu pengabdian tersebut meliputi berbagai aspek, termasuk pada sekolah maupun madrasah swasta juga pemberdayaan masyarakat.

Dalam masalah ini yang dipilih adalah pengabdian pada madrasah oleh karena itu Pendampingan ini dilakukan dengan mengambil sasaran madrsah swasta yaitu "Pelatihan Karya Tulis dan Majalah Dinding Bagi Siswa Madrasah Tsanawiyah Al Madaniyah Jempong Ampenan Mataram". Kegiatan pengabdian dilakukan agar dosen perguruan tinggi dalam hal ini (UIN) 
Universitas Islam Negeri Mataram tidak hanya melakukan rutinitas sebatas mengajar , tetapi lebih merupakan implementasi nilai-nilai akademis agar lebih bermanfaat untuk Madrasah yang membutuhkan bimbingan. Upaya-upaya kongkrit diperlukan sehingga memiliki nilai yang dapat dinikmati oleh masyarakat luas. Dosen perguruan tinggi tidak hanya memiliki kewajiban membimbing mahasiswa dan mengabdi kepada perguruan tinggi bersangkutan akan tetapi juga memiliki kewajiban melakukan pembinaan, bimbingan, arahan, dampingan kepada masyarakat maupun lembaga lainnya.

Salah satu faktor penting dalam mencapi tujuan pembelajaran yaitu kompetensi pendidik. Kemampuan mengajar memerlukan seperangkat pengetahuan dan keterampilan tertentu agar guru dapat melaksanakan tugasnya dengan semestinya. Kemampuan mengajar itu mulai dibentuk di lembaga pendidikan guru (pendidikan prajabatan), dan selanjutnya ditingkatkan/ dikembangkan melalui pembinaan dalam jabatan di lapangan, yang dapat dilakukan dengan usaha mandiri maupun dengan bantuan orang lain.

Terdapat beberapa alasan yang menjadi dasar dari pentingnya pembinaan bagi siswa dalam karya tulis dan pembuatan majalah dinding, yaitu:

1. Menjadi optimal eksplorasi potensi menulis dan kreasi siswa dalam rangka membangun budaya tulis diklangan siswa

2. Siswa dapat menghasilkan karya tulis dan karya majalah dinding yang dapat terbit secara berkala dan dibaca banyak orang pada lingkungan madrasah, dan

3. Siswa dapat memanfaatkan media sosial untuk publikasi karya-karyanya.

4. Terdapat keberlanjutan kegiatan menulis dan majalah dinding yang dikelola oleh siswa dengan pembinaannpihak madrasah.

Dengan kegiatan dimaksud sangat bermakna dalam membangun budaya menulis bagi siswa, yang saat ini secara umum masyarakat Indonesia sangat rendah budaya menulisnya bila dibandingkan negara tetangga. Juga agar para siswa dapat memanfaatkan media sosial lebih positif dan produktif.

Sebagai upaya inovasi dalam Sistem Pendidikan Islam, madrasah tidak lepas dari berbagai tantangan yang dihadapi. Tantangan-tantangan tersebut, menurut Darmu'in (1998), antara lain:

1. Madrasah telah terkikis akar sejarahnya, artinya keberadaan madrasah bukan merupakan kelanjutan pesantren, meskipun diakui bahwa pesantren merupakan bentuk lembaga pendidikan Islam pertama di Indonesia.

2. Terdapat dualisme pemaknaan terhadap madrasah. Di satu sisi, madrasah diidentikkan dengan sekolah karena memiliki muatan secara kurikulum yang relatif sama dengan sekolah umum. Di sisi lain, madrasah dianggap sebagai pesantren dengan sistem klasikal yang kemudian dikenal dengan madrasah diniyah.

Namun dalam konteks nomor 2 tersebut diatas penulis melihan sebagai ke arifan dengan mengakomodasi kekhasan islam dalam sistem Pendidikan di Indonesia. Kekhasan sistem pendidikan di Indonesia telah menjadi peluang bagi pendidikan khas islam yaitu madrasah untuk tumbuh dan berkembang serta berkompetisi dengan sekolah umum dibawah naungan kementrian pendidikan. Dengan sistem tersebut ada perkembangan sangat menggembirakan 
atas animo siswa masuk madrasah bukan karena keterpaksaan, namun sebagai pilihan; sebagai contoh pada rekrutmen tahun ini di MTsN 1 Mataram dengan pola persayaratan yang ketat jumlah pendaftar lebih dari 1200 calon, sedangkan yang lulus dapat diterima tidak lebih dari 300 siswa, begitu pula terjadi di MAN 1 dan MAN 2 rencana penerimaan 300 siswa dengan jumlah pendaftar lebih dari 1500 calon siswa, dan ini artinya madrasah punya citra baik dikalangan masyarakat luas dari berbagai kalangan.

Dengan demikian, sebagai sub sistem pendidikan nasional, madrasah telah beranjak membangun jati diri yang dapat ada kelebihan dari lembaga pendidikan lainnya. Dengan pensejajaran madrasah dengan sekolah umum , maka ada kebijakan proporsi pendidikan agama dari $60 \%$ agama dan $40 \%$ umum menjadi $30 \%$ agama dan $70 \%$ umum. Memang hal ini tantangan yang perlu kerja keras dan kearifan dalam menghadapi tantangan agar eksistensi pendidikan Islam terus tumbuh dan berkembangn. Beberapa tantangan yang muncul kemudian, antara lain:

1. Atas berkurangnya muatan materi pendidikan agama. Hal ini dilihat sebagai upaya penambahan materi umum agar sejajar dengan sekolah. Selanjutnya bagaimana memperoleh cara, trik, metode dengan kurikulum agama yang terbatas mampu mencetak muslim sejati atau beraklahul karimah.

2. Tamatan madrasah memiliki kecakapan beragama dan kecakapan umum yang kompetitif.

Diakui bahwa model pendidikan madrasah di dalam perundang-undangan negara, memunculkan tantangan dan peluang sistem Pendidikan di Indonesia. Tantangan dan peluang pendidikan di Indonesia telah menjadi pekerjaam berat yang dihadapi dan menampakkan hasil hingga sekarang. Tantangan dan peluang ini tidak hanya berkenaan dengan sistem pengajarannya tetapi juga menjurus pada keilmuannya. Pola pikir yang yang integrative diharapkan dapat menyudahi gap antara ilmu-ilmu agama Islam dan ilmu-ilmu umum. Sebagai contoh dalam penilaian seakan-akan muncul ilmu Islam dan ilmu bukan Islam (kafir).Dengan pengintegrasian keilmuan ini menjadi garapan bagi para pakar pendidikan Islam untuk berusaha menyatukan keduanya.

Tantangan dan peluang pendidikan Islam juga muncul dalam bidang manajerialnya, khususnya di lembaga swasta. Lembaga swasta umumnya memiliki dua top manager yaitu kepala madrasah dan ketua yayasan (atau pengurus). Meskipun telah ada garis kewenangan yang memisahkan kedua top manager tersebut, yakni kepala madrasah memegang kendali akademik sedangkan ketua yayasan (pengurus) membidangi penyediaan sarana dan prasarana, sering di dalam praktik terjadi overlapping. Masalah ini biasanya lebih buruk jika di antara pengurus yayasan tersebut ada yang menjadi staf pengajar. Di samping ada kesan memataimatai kepemimpinan kepala madrasah, juga ketika staf pengajar tersebut melakukan tindakan indisipliner (sering datang terlambat), kepala madrasah merasa tidak berdaya menegumya.

Praktek manajemen di madrasah sering menunjukkan model manajemen tradisional, yakni model manajemen paternalistik atau feodalistik. Dominasi senioritas semacam ini terkadang mengganggu perkembangan dan peningkatan kualitas pendidikan. Munculnya kreativitas inovatif dari kalangan muda terkadang dipahami sebagai sikap yang tidak menghargai senior. Kondisi yang demikian ini mengarah pada ujung ekstrem negatif, hingga 
muncul kesan bahwa meluruskan langkah atau mengoreksi kekeliruan langkah senior dianggap tabiat su'ul adab.

Tantangan dan peluang pengelolaan pendidikan juga terjadi pada pembinaan yang dilakukan oleh departemen yaitu Departemen Pendidikan Nasional (Depdiknas) dan Departemen Agama (Depag). Pembinaan Madrasah di bawah naungan Depag berhadapan dengan Sekolah umum di bawah pembinaan Depdiknas sering menimbulkan kecemburuan sejak di tingkat (SD dan MI) hingga perguruan tinggi. Dari alokasi dana, perhatian, pembinaan manajerial, bantuan buku dan media pembelajaran, serta penempatan guru, hingga pemberian beasiswa pendidikan lanjut sering tidak sama antara yang diterima oleh sekolah umum (Depdiknas) dengan madrasah (Depag).

Kesenjangan antara madrasah swasta dan madrasah negeri pun tampaknya juga menjadi masalah yang belum tuntas diselesaikan. Gap tersebut meliputi beberapa hal seperti pandangan guru, sarana dan prasarana, kualitas input siswa dan sebagainya yang kesemuanya itu berpengaruh baik langsung maupun tidak langsung kepada mutu pendidikan. Yang demikian ini karena munculnya SKB tiga menteri tersebut belum diimbangi penyediaan guru, buku-buku dan peralatan lain dari departemen terkait (Malik Fadjar, 1998).

Sedangkan dalam pembinaan potensi siswa masih sering terabaiakan karena alasan; sarana prasarana yang kura, guru Pembina tidak ada, siswanya malas dan banyak lagi alasan lain. Namun pada kenyataannya potensi siswa belum tergarap dengan baik sebagai wahana dalam pembentukkan karakter.Maka, kegiatan pendampingan dan pembinaan ini difokuskan pada,"Pelatihan Karya Tulis dan Majalah Dinding Bagi Siswa Madrasah Tsanawiyah Al Madaniyah Jempong Ampenan Mataram".

\section{Metode}

Proses pembelajaran membutuhkan metode pengajaran tertentu dari instruktur. Metode pengajaran dapat berbentuk ceramah, demonstrasi, diskusi, serta praktek yang bertujuan untuk memberikan pemahaman pengetahuan, pemahaman aplikasi dan pemahaman analisis, sintesis serta evaluasi (Syah, 2002 : 202).

Untuk itu pada pelatihan penulisan majalah dinding menggunakan metode ceramah dan simulasi praktek. Kegiatan pengabdian ini ditujukan untuk siswa melalui strategi pelaksanaan dengan langkah-langkah yaitu:

1. Optimalisasi fungsi potensi menulis dikalangan siswa yang diarahkan dengan cara-cara dan metode tertentu yang menggembirakan, menantang dan menarik.

2. Memberikan sejumlah materi tentang cara dan trik trik menulis dan pembuatan majalah dinding.

3. Memberikan kesempatan bagi setiap peserta pelatihan praktek pada setiap sesi serta melakukan refleksi.

4. Membimbing peserta peserta untuk menyrlesaiakan karya tulisnya sehingga menjadi satu karya bersama. Dan menghasilkan majalah dinding pada setipa level kelas. Yang selanjutnya dapat berkrya dan menampilkan secara kelompok. 
5. Mengajarkan dan membimbing cara pemanfaat media sosial yang baik dan produkti bagi siswa; diantaranya blok, WA, instagram, line dan lainnya.

\section{Hasil dan Pembahasan}

Pengabdian kepada masyarakat yaitu madrasah binaan di Madrasah Tsanawiyah Al Madaniyah Jempong Ampenan Mataram. Pengabdian ini dimulai pada tanggal 17 Oktober 2018 hingga 19 Oktober 2018.Pada Pukul 13.00 Wita s/d 17.30 Wita, Pengabdian diawali dengan pengajuansurat ijin pengabdian kepada Kepala Madrasah Tsanawiyah Al Madaniyah Jempong Ampenan Mataram pada yaitu tanggal 11 Oktober 2018. Menanggapi surat ijin tersebut, Kepala Madrasah Tsanawiyah Al Madaniyah Jempong Ampenan Mataram mengijinkan peneliti untuk mengadakan pengabdian di Madrasah Tsanawiyah Al Madaniyah Jempong Ampenan Mataram pada tanggal 17 Oktober 2018.

Subjek pengabdian sebanyak 20 siswa yang terdiri dari 10 siswa laki-laki dan 10 siswiperempuan. Pengabdian ini dilakukan selama 3(tiga) hari di Madrasah Tsanawiyah Al Madaniyah Jempong Ampenan Mataram, yang berfokus pada pemberian materi/ konsep karya tulisdan majalah dinding serta langsung praktik. Selama kegiatan tersebut, peneliti melakukan wawancara seputar pengetahuan guru tentang karya tulis dan majalah dinding. Dari para siswa dapat diperoleh gambaran bahwa materi yang diberikan oleh pembicara (pemateri) sesuai dengan kebutuhan para siswa yaitu para siswa yang menginginkan adanya tulisan yang berupa karya tulisuntuk dimuat di majalah dinding sekolah agar mereka bisa dapat membina hubungan baik dengan siswa lainya dengancara menyebarkan informasi lewat majalah dinding.

Terdapat kecenderungan bahwa para siswa di sekolah ini pun belum memiliki pengetahuan yang komprehensif mengenai langkah-langkah membuat tulisan karya tulis untuk majalah dinding, sehingga mereka banyak menanyakan hal-hal yang sangat mendasar sekali mengenai tulisan untuk majalah dinding, misalnya pertanyaan darimana kita mulai menulis, kemudian apa manfaat membuat tulisan untuk majalah dinding dan tulisan apa saja yang harus ada dalam majalah dinding.

Majalah dinding berfungsi bukan sekadar sebagai media komunikasi antara siswa dengan siswa dan siswa dengan sekolah/penyelenggara. Majalah dinding memiliki fungsi sebagai media pembelajaran bagi siswa untuk mengembangkan ketrampilan menulis. Minat dan kegemaran menulis bisa dimulai dan dikembangkan melalui majalah dinding. Fungsi ini bisa maksimal ketika majalah dinding dikelola secara serius. Serius artinya pihak sekolah harus memberi pendampingan kepada para siswanya. Pendampingan bisa dilakukan oleh guru bahasa atau guru yang berminat pada bidang jurnalistik karena majalah dinding ini terkait dengan kegiatan tulis menulis dan publikasi. Sekolah bisa menggunakan jasa tenaga dari luar yang memang biasa dan mau focus menghandle majalah dinding.

Seorang siswa yang tertarik mengembangkan majalah dinding harus membuat rencana kerja yang meliputi; penetapan tema dan periodesasi terbit. Tema harus menarik dan sesuai dengan usia anak yang terlibat didalamnya. Melihat satu tahun pelajaran, siswa dapat membuat tema sesuai dengan kalender pendidikan, misalnya Januari tema happy new year; Feberuari 
tema valentine; dan seterusnya. Sedangkan untuk terbitan siswa dapat merancang bulanan sesuai tema. Dengan demikian majalah dinding menjadi tempat bagi para siswa belajar menyusun program kerja.

Pembuatan majalah dinding ini pada prosesnya tidak hanya menjadi tempat belajar menulis tetapi juga berorganisasi yang baik bagi para siswa. Didalam tim majalah dinding para siswa akan belajar membuat program, disiplin waktu karena time schedule, kerja sama dan bagaimana menghargai orang lain. Banyak values direfleksikan dan dihidupi didalam pengembanganmajalah dinding. Majalah dinding menjadi media yang efektif untuk pendidikan karakter. Sungguh asik dan menyenangkan terlibat dalam pengembangan majalah dinding disekolah karena Anda akan belajar dan menemukan banyak values didalamnya.

Majalah dinding yang dikelola secara serius akan memberi nilai promotive bagi sekolah. Kreasi dan prestasi para siswa dapat ditampilkan pada majalah dinding, dan hal ini adalah promosi yang sangat murah sekaligus efektif kepada masyarakat. Kebutuhan Penghargaan Terpenuhi. Menurut psikolog behaviorisme, Abraham Maslow dalam diri setiap manusia terdapat hirarki kebutuhan yang tidak mungkin kebutuhan yang lebih tinggi terpenuhi sebelum kebutuhan yang lebih rendah tercukupi. Salah satu kebutuhan manusia adalah kebutuhan untuk dihargai. Jikalau kebutuhan untuk dihargai ini telah terpenuhi maka ia akan berusaha memenuhi kebutuhan aktualisasi diri sebagai kebutuhan tertinggi. Majalah dinding memberi keluasan bagi para siswa untuk memenuhi kebutuhan akan penghargaan. Misalnya, tulisan dan karya siswa yang dipublikasikan di majalah dinding akan memberi penghargaan istimewa bagi yang bersangkutan. Dalam proses yang terjadi Anda akan menemukan hal-hal luar biasa, dengan catatan aktivitas ini sungguh diminati dan disukai.

Karya tulis merupakan hasil karangan dalam bentuk tulisan atau karangan yang mengetengahkan hasil pikiran, hasil pengamatan, tinjauan dalam bidang tertentu yang disusun secara sisteatis.Karya tulis juga dapat dikatakan tulisan yang membahas tentang masalah tertentu berdasarkan pengamatan secara sistematis dan terarah.Ada yang mengatakan karya tulis itu sebagai gagasan seseorang yang dituangkan dalam bentuk tulisan (Suherli, 2010:2). Dari berbagai pengertian yang ada pada dasarnya mempunyai arti yang sama namun dapat disimpulakan bahwa karya tulis merupakan hasil karya seseorang yang dituangkan dalam bentuk tulisan.

Dalam hal ini siswa di paparkan mengenai karya tulis dan diajarkan dalam mempraktikkan bagaimana cara membuat karya tulis. Salah satu contoh karya tulis non ilmiah yaitu dogeng, cerpen, novel, drama, roman, puisi dan pantun. Karya tulis yang di paraktikkan oleh siswa di tuangkan dalam majalah dinding tujuannya agar hasil karya tulis mereka dapat di baca dan menjadi inspirasi serta wawasan bagi siswa lainnya.

Majalah dinding berfungsi bukan sekadar sebagai media komunikasi antara siswa dengan siswa dan siswa dengan sekolah/penyelenggara. Mading memiliki fungsi sebagai media pembelajaran bagi siswa untuk mengembangkan ketrampilan menulis. Minat dan kegemaran menulis bisa dimulai dan dikembangkan melalui mading. Fungsi ini bisa maksimal ketika mading dikelola secara serius. Serius artinya pihak sekolah harus memberi pendampingan kepada para siswanya. Pendampingan bisa dilakukan oleh guru bahasa atau guru yang berminat pada bidang 
jurnalistik karena mading ini terkait dengan kegiatan tulis menulis dan publikasi. Sekolah bisa menggunakan jasa tenaga dari luar yang memang biasa dan mau focus menghandle mading.

Seorang siswa yang tertarik mengembangkan mading harus membuat rencana kerja yang meliputi; penetapan tema dan periodesasi terbit. Tema harus menarik dan sesuai dengan usia anak yang terlibat didalamnya. Melihat satu tahun pelajaran, siswa dapat membuat tema sesuai dengan kalender pendidikan, misalnya Januari tema happy new year; Feberuari tema valentine; dan seterusnya. Sedangkan untuk terbitan siswa dapat merancang bulanan sesuai tema. Dengan demikian mading menjadi tempat bagi para siswa belajar menyusun program kerja.

Pembuatan mading ini pada prosesnya tidak hanya menjadi tempat belajar menulis tetapi juga berorganisasi yang baik bagi para siswa. Didalam tim mading para siswa akan belajar membuat program, disiplin waktu karena time schedule, kerja sama dan bagaimana menghargai orang lain. Banyak values direfleksikan dan dihidupi didalam pengembangan mading. Mading menjadi media yang efektif untuk pendidikan karakter. Sungguh asik dan menyenangkan terlibat dalam pengembangan majalah dinding disekolah karena Anda akan belajar dan menemukan banyak values didalamnya.

Majalah dinding yang dikelola secara serius akan memberi nilai promotive bagi sekolah. Kreasi dan prestasi para siswa dapat ditampilkan pada majalah dinding, dan hal ini adalah promosi yang sangat murah sekaligus efektif kepada masyarakat. Kebutuhan Penghargaan Terpenuhi. Menurut psikolog behaviorisme, Abraham Maslow dalam diri setiap manusia terdapat hirarki kebutuhan yang tidak mungkin kebutuhan yang lebih tinggi terpenuhi sebelum kebutuhan yang lebih rendah tercukupi. Salah satu kebutuhan manusia adalah kebutuhan untuk dihargai. Jikalau kebutuhan untuk dihargai ini telah terpenuhi maka ia akan berusaha memenuhi kebutuhan aktualisasi diri sebagai kebutuhan tertinggi. Majalah dinding memberi keluasan bagi para siswa untuk memenuhi kebutuhan akan penghargaan. Misalnya, tulisan dan karya siswa yang dipublikasikan di mading akan memberi penghargaan istimewa bagi yang bersangkutan. Dalam proses yang terjadi Anda akan menemukan hal-hal luar biasa, dengan catatan aktivitas ini sungguh diminati dan disukai.

Majalah dindingharus dirancang secara sederhana tetapi menarik. Sederhana karena majalah dinding bukan majalan professional yang mengeluarkan dana yang besar. Sederhana dalam arti, peralatan dan sarana yang diperlukan upayakan memanfaatkan barang-barang yang tidak mahal dan sangat baik jika memanfaatkan barang bekas (daur ulang) Ini sebuah pola berpikir yang tanamkan kepada siswa. Tentu aspek menarik harus diperjuangkan, bisa dilakukan dengan mengembangkan kreativitas siswa. Bayangkan setiap sudut ruangan luar gedung sekolah menjadi media untuk majalah dinding yang apik dan ilmiah. Tentu situasi ini akan menjadikan sekolah makin indah dan menarik dihuni oleh para siswa.

Majalah dinding sering dipandang sebelah mata keberadaanya. Sedikit sekolah mengembangkan majalah dinding sebagai kegiatan ekstrakurikuler. Padahal majalah dinding sungguh memiliki kekuatan besar untuk mengembangkan minat siswa menulis. Ketika sekolah mengabaikan kegiatan ini, sekolah telah membuang unsur penting dalam pendidikan yakni proses berpikir karena majalah dinding adalah pembelajaran menulis, dan "menulis adalah proses berpikir". Selain itu, pihak sekolah akan sangat diuntungkan ketika akreditasi sekolah 
tiba karena salah satu instrument akreditasi adalah pengembangan kreativitas siswa dan budaya ilmiah dilingkungan sekolah. Majalah dinding adalah media efektif untuk mengembangkan kreativitas siswa dan budaya ilmiah di lingkungan sekolah.

Karena majalah dinding merupakan salah satu jenis media komunikasi massa tulis yang paling sederhana dan sangat mungkin dibuat oleh siswa, maka majalah dinding sangat tepat bila digunakan sebagai media unjuk karya dalam Gerakan Literasi Sekolah. Adapun dalam hal pembuatannya, majalah dinding ini dapat disusun secara periodik oleh peserta didik dalam kelompoknya. Sedangkan penempatannya, bisa diletakkan pada dinding kelas-kelas, koridor sekolah ataupun tempat-tempat lain yang strategis sehingga siswa akan lebih mudah dalam membacanya.

Agar para peserta didik termotivasi dalam menunjukkan karyanya melalui majalah dinding, kiranya sekolah perlu membuat inovasi-inovasi seperti memberikan rewardkepada majalah dinding terbaik yang disusun oleh peserta didik. Atau pihak sekolah juga bisa memberikan reward kepada penulis-penulis terbaik yang karyanya terpampang dalam majalah dinding tersebut dengan berbagai macam kategori sesuai dengan rubrik-rubrik yang ada pada majalah dinding. Mudah-mudahan melalui kegiatan tersebut peserta didik dapat lebih termotivasi dalam melaksanakan kegiatan Gerakan Literasi Sekolah, sehingga tujuan dari pelaksanaan program tersebut dapat tercapai dengan maksimal.

Berbagai kreasi dan variasi model dan tampilan majalah dinding dibuat dalam rangka meningkatkan keterampilan siswa dalam membaca, terlebih menulis. Siswa diajarkan bagaimana mengelola sebuah media mini seperti majalah dinding sekolah, selain itu dilatih untuk meningkatkan kemampuan berorganisasi yakni bagaimana secara efektif dan efisien mengelola media. Diharapkan siswa-siswi yang berkecimpung dalam dunia majalah dinding akan mengembangkan pasca lulus dari sekolah. Misalnya melanjutkan pendidikan ke perguruan tinggi mengambil jurusan bahasa, sastra, jurnalis atau ilmu komunikasi. Selain itu, kemampuan menulis akan mengantarkan alumni sekolah bisa bersaing dalam dunia akademik seperti kemampuannya menulis karya ilmiah karena sudah terlatih di usia sekolah.

Meski begitu, secara keseluruhan pemanfaatan majalah dinding di sekolah-sekolah di Alor belum begitu masif. Berapa sekolah yang benar-benar memanfaatkan majalah dinding sekolah. Sekolah-sekolah papan atas di Alor saja pemanfaatan majalah dindingnya belum begitu baik dikelola pihak OSIS dan pembina OSIS/OSIM. Putaran edisi penerbitan majalah dinding masih tersendat-sendat dikarenakan keterbatasan waktu siswa hingga mungkin saja keterbatasan dana serta fasilitas penunjang. Ada kecenderungan pihak sekolah dan OSIM/OSIS kurang memperhatikan pengelolaan majalah dinding sekolah/madrasah.

Untuk itulah perlu didiskusikan bagaimana sebaiknya menghidupkan kembali majalah dinding sekolah yang kelihatannya tidak begitu baik dikelola. Bagaimana langkah-langkah taktis yang harus dibuat agar proses pengelolaan majalah dinding bisa berjalan sebagaimana mestinya. Serta bagaimana meningkatkan partisipasi siswa dalam menuangkan ide-ide atau gagasan serta kreativitasnya melalui papan majalah dinding yang telah disediakan.

Majalah dinding merupakan wahana untuk menerapkan kemampuan siswa terutama dalam bidang tulis menulis. Tulisan-tulisan yang ada di dalam sebuah majalah dinding, pada 
umumnya merupakan bahan ajar yang ada dalam kurikulum bahasa Indonesia. Pada kurikulum bahasa Indonesia juga terdapat kompetensi seperti penulisan berita, opini, resensi, cerpen, puisi, tajuk rencana, artikel, dan sebagainya. Saat ini perkembangan jurnalistik sangat pesat di kalangan pelajar. Hal itu dapat dilihat dari maraknya perlombaan-perlombaan tentang jurnalistik. Salah satu contoh yang nyata, diadakannya lomba majalah dinding antar kelas di jurusan Pendidikan Bahasa dan Sastra Indonesia yang dilaksanakan setiap bulan Oktober dalam rangka merayakan Bulan Bahasa. Selain itu, sering juga diadakan lomba-lomba majalah dinding antar sekolah dan antar kelas di lingkungan sekolah itu masing-masing (Ayu \& Dewi, 2013).

Arikunto (2014) merilis urutan makna pengelolaan majalah dinding meliputi tahapan perencanaan, pelaksanaan, pasca pasang dan penilaian. Jika dilihat dari urutannya maka kegiatan pengelolaan majalah dinding merupakan program/sistem yang juga melalui tahapan fungsi-fungsi manajemen sehingga membutuhkan komitmen yang kuat dalam mewujudkan tujuan dari pengelolaan sebuah majalah dinding sekolah. Fakta membuktikan bahwa tidak semua sekolah di Indonesia memiliki majalah dinding, selain itu beberapa di antaranya yang memiliki majalah dinding namun pengelolaannya masih cukup memprihatinkan, namun ada juga yang sudah baik pengelolaannya kendati tetap saja ada kekurangan yang teridentifikasi.

Banyak di antara pengelolaan majalah dinding yang bermasalah pada tahapan pasca pasang, hal ini karena setelah majalah dinding itu terpasang dalam jangka waktu yang direncanakan maka karya-karya yang ada dalam majalah dinding biasanya tempatnya adalah di tong sampah dan nasib akhirnya menjadi abu sisa pembakaran. Padahal hasil majalah dinding pasca pasang bisa dimanfaatkan untuk dikumpulkan dan dijilid dalam bentuk bundelan dan diberi judul kumpulan majalah dinding edisi tertentu yang pada akhirnya bisa disimpan di perpustakaan sekolah untuk dimanfaatkan lebih lanjut sebagai tambahan pengetahuan siswa dan seluruh warga sekolah bahkan menjadi wadah pengakuan karya siswa dan menjadi kebanggaan dan kenangan tersendiri untuk siswa bersangkutan. Pengelolaan majalah dinding harus dicari format dan pengelolaan yang baik karena menyangkut upaya sekolah membangkitkan kreativitas dan menggali segala potensi siswa yang terpendam.

Beberapa cara menghidupkan pengelolaan majalah dinding sekolah di antaranya adalah dengan memperkuat struktur OSIM/OSIS dan pengelola majalah dinding sehingga dapat bekerja sesuai dengan tugas dan tanggung jawabnya. Selain itu sekolah harus mendukung dalam hal materi maupun moril sehingga fasilitas dan roda perputaran edisi majalah dinding dapat berjalan dengan baik.

Salah satu ide menarik lainnya adalah perlu dilakukan perlombaan majalah dinding antara sekolah yang bisa difasilitasi oleh Dinas Pendidikan atau Kementrian Agama Agama atau diselenggarakan oleh satu sekolah. Sementara sekolah lain menjadi partisipan. Perlombaan bisa dilakukan pada bulan bahasa sebagaimana sekarang ini beberapa sekolah sedang melakukan perlombaan dalam rangka memperingati bulan bahasa. Ego dan gengsi sekolah bisa menjadi pemicu semangat para siswa untuk berkreativitas melalui majalah dinding. Majalah dinding sekolah bisa dimanfaatkan guru mata pelajaran untuk memberikan tugas kepada siswa misalnya mencari atau membuat artikel sederhana yang berkaitan dengan materi ajar yang sedang 
diajarkan atau melakukan kajian/penafsiran terhadap karya-karya seperti puisi, cerpen, pantun dan lain sebagainya sehingga ada sinergisitas antara ranah akademik dan ekstrakurikuler.

Untuk meningkatkan partisipasi siswa dalam mengisi karya-karya di majalah dinding sekaligus menjadi penikmat majalah dinding maka beberapa hal yang harus dilakukan di antaranya yakni keaktivan pengurus OSIM/pengelola majalah dinding untuk mengajak para siswa menuangkan ide dan kreativitasnya, selain itu guru-guru juga diharapkan memotivasi para siswa untuk berpartisipasi dalam menuangkan ide-ide dalam pengelolaanmajalah dinding. Para siswa yang paling rajin menuangkan ide seharusnya diberikan penghargaan oleh pihak sekolah dalam bentuk piagam dan bentuk lainnya sehingga memotivasi siswa yang lain untuk terlibat aktif menulis bahan-bahan majalah dinding. Jika majalah dinding yang telah habis masa pasang dimanfaatkan lebih lanjut menjadi kliping dan kumpulan karya majalah dinding dalam beberapa edisi dan disimpan di perpustakaan menjadi bahan bacaan maka akan semakin memancing motivasi dan semangat siswa untuk menulis karena merasa karya mereka dihargai.

\section{Kesimpulan}

Kesimpulan pelaksanaan kegiatan pengabdian ini adalah sebagai berikut:

1. Secara kognitif ada peningkatan pengetahuan siswa dalam penulisan karya tulis dan majalah dinding.

2. Siswa memiliki keterampilan dasar dalam menulis karya tulis dan membuat majalah dinding.

3. Siswa dapat menuangkan ide kreatif dalam mengembangkan hasil kreasi dan variasi model keterampilan dalam karya tulis dan majalah dinding.

4. Siswa dapat menerbitkan hasil karya tulis mereka dalam majalah dinding.

\section{Referensi}

Darmuin (1998). Prospek Pendidikan Islam di Indonesia: Suatu Telaah terhadap Pesantren dan Madrasah. Dalam Chabib Thoha dan Abdul Muth'i. PBM-PAI di Sekolah: Eksistensi dan Proses Belajar Mengajar Pendidikan Agama Islam. Yogyakarta: Pustaka Pelajar bekerja sarna dengan Fakultas Tarbiyah IAIN Walisongo Semarang.

Fadjar, M.A. (1998). Madrasah dan Tantangan Modernitas. Bandung: Mizan.

Kadri,dkk.2010, Pemberdayaan Masyarakat: Strategi dan Pengalaman Aksi, Yogyakarta: Kurnia Kalam Semesta kerjasama dengan Nusa Tenggara Centre Mataram.

Mustaqim Sirathal. (2008). Penguatan Masyarakat Dengan Program CD. Dalam http://1.blot.spot.com. 27 April 2014.

Panduan Bantuan Peningkatan Mutu Program Pengabdian Kepada Masyarakat tahun 2014, Direktorat Pendidikan Tinggi Islam Direktorat Jenderal Pendidikan Islam Kementerian Agama RI, 2014.

https://www.google.com/url?sa=t\&rct=j\&q=\&esrc=s\&source=web\&cd=5\&ved=0CFIQFjAE\&url=ht tps\%3A\%2F\%2Fitja.wordpress.com\%2Fcategory\%2Fmanajemen-

kelembagaan\%2F\&ei=JLVfU8PZHCj_8QXAqoGwDw\&usg=AFQjCNHTLDMy6IqzZmqVsWd4SAxy 7YXwWA\&sig2=4KP78PZSffOb3IswW59wYg di akses tanggal 29 April 2014.

http://jorjoran.wordpress.com/2011/06/19/makalah-manajemen-lembaga-pendidikan-islam/ diakses tanggal 30 April 2014.

Zamhariri (2008), Pengembangan Msyarakat: Perspektif Pemberdayaan dan Pembangunan, Komunitas, Jurnal Pengembangan Masyarakat Islam, Vol 4, no. 1 